\title{
Between territories and knowledge practices. Challenges with indigenous teacher training in Brazil
}

\author{
Ana Maria R. Gomes · Shirley A. de Miranda • Marina de L. Tavares
}

Received: 10 September 2020 / Accepted: 1 October 2020 / Published online: 8 December 2020 (C) Springer Fachmedien Wiesbaden GmbH, ein Teil von Springer Nature 2020

\begin{abstract}
In Brazil, indigenous claims for the right to maintain their specific ways of living and thinking, maintaining and using their own languages, cultures, and modes of production, and the re-elaboration and transmission of knowledge have resulted in the development of intercultural teacher training programs in Brazilian universities. The discussions presented here take as a reference the experiences of the authors in the Intercultural Training Course for Indigenous Educators (FIEI) developed and offered at the Federal University of Minas Gerais (UFMG) since 2006. We highlight significant aspects of the training of indigenous teachers in the constant flow between villages and university in progressive processes of deterritorialization and reciprocal recognition. We present the approach to the notion of territory that supports our analysis and describe three curricular components of the course from the perspective of different territorialities: the teaching internship, the intermodules in a specific qualification, and the research monographs resulting from "academic paths." We conclude that the FIEI experience is not only a training process for indigenous students, but it also engenders the transformation of everyone involved.
\end{abstract}

Keywords Indigenous education · Indigenous territory · Indigenous teachers · Xakriabá · Pataxó

Prof. Dr. A. M. R. Gomes $(\varangle) \cdot$ Ass. Prof. Dr. S. A. de Miranda · Ass. Prof. Dr. M. de L. Tavares Faculdade de Educação, Departamento de Ciências Aplicadas a Educação, Universidade Federal de Minas Gerais, Av. Antônio Carlos 6.627, 31270-901 Belo Horizonte, Minas Gerais, Brazil E-Mail: anagomes@ufmg.br

Ass. Prof. Dr. S. A. de Miranda

E-Mail: smiranda@ufmg.br

Ass. Prof. Dr. M. de L. Tavares

E-Mail: marina-tavares@ufmg.br 


\section{Zwischen Territorien und lokalen Wissenspraktiken. Herausforderungen der indigenen Lehrer*innenausbildung in Brasilien}

Zusammenfassung In Brasilien führten die Forderungen der Indigenen, ihre spezifischen Lebens- und Denkweisen beizubehalten, ihre eigenen Sprachen, Kulturen und Produktionsweisen zu erhalten und zu praktizieren sowie Forderungen nach dem Wiederaufbau ihres Wissens und dessen Weitergabe zur Entwicklung einer interkulturellen Lehrer*innenbildung an brasilianischen Universitäten. Die hier vorgestellten Überlegungen basieren auf den Erfahrungen der Autor*innen im Rahmen des Studiengangs Formação Intercultural para Educadores Indígenas (FIEI, Interkulturelle Ausbildung für indigene Pädagog*innen), der seit 2006 an der Bundesuniversität von Minas Gerais (UFMG) entwickelt wird. Dabei zeigen wir wesentliche Aspekte der Ausbildung indigener Lehrer*innen auf, etwa den bestständigen Wechsel zwischen ihren Dörfern und den Universitäten sowie den durch diese Deterritorialisierung und gegenseitige Anerkennung ausgelösten emanzipatorischen Prozess. Zentral ist dafür unser Begriff des Territoriums, als analytisches Werkzeug, um drei Bestandteile des Curriculums aus unterschiedlichen territorialen Perspektiven zu betrachten: das Lehrpraktikum, die Spezialisierungsmöglichkeit durch „Übergangsmodule“ sowie die forschungsorientierten Abschlussarbeiten, die aus einem je besonderen akademischen „Pfad“ heraus entstehen. Eine wesentliche Schlussfolgerung aus dem FIEIStudiengang ist dabei, dass dieser nicht nur eine Ausbildung für indigene Studierende ist, sondern sie einen transformatorischen Bildungsprozess aller Beteiligten bewirkt.

Schlüsselwörter Indigene Erziehung · Indigenes Territorium · Indigene Lehrende · Xakriabá · Pataxó

\section{Introduction}

The training of indigenous teachers at a higher degree level in Brazil has been recently introduced in the scope of broader discussions regarding teacher training, in a direct relationship with the reconfiguration of schools' social function, that were carried out by indigenous peoples. In Silva's (2001) analysis, the context of the 1980s was marked by indigenous peoples' claims for recognition of their right to maintain their specific ways of living and thinking, to preserve and use their languages and cultures, and to apply their own ways of production, re-elaboration, and transmission of knowledge (Silva 2001, p. 10). Proposals for specific degree courses for the training of indigenous teachers received a decisive boost with the creation of PROLIND—Support Initiative for Indigenous Peoples' Intercultural Higher Education, which started in 2004 and was developed by the Ministry of Education through the Secretariat for Continuing Education, Literacy and Diversity (MEC-SECAD). The initiative aimed to support projects for specific degree courses for the training of indigenous educators to teach in schools in their villages. This training should integrate teaching, research, and outreach activities and promote the value of studying 
topics such as mother tongues, territorial management, and sustainability, as well as indigenous peoples' history and culture. ${ }^{1}$

From the legal point of view, the claims for indigenous recognition outlined the break with the integrationist paradigm that was in force in the legal apparatus, which provided for the incorporation of the so-called forest people (silvícolas) into the national community through its renunciation of their indigenous identity. The violent methods used to remove the link with a specific identity, including schooling, were supported by this paradigm.

The struggle for the right to land establishes the link between indigenous peoples worldwide, united by their condition of having been expropriated and by their struggle for recognition of their rights (Smith 2018, p. 133). In Brazil this struggle produced the indigenous movement and was expressed in the 1988 Federal Constitution as a right to ethnic, linguistic, and cultural diversity, without damaging their prerogatives as Brazilian citizens (Munduruku 2012, p. 37).

Unlike previous legislation, the 1988 Brazilian Federal Constitution contains $\S$ VIII (Regarding the Indigenous Peoples), which is part of Title VIII (Regarding the Social Order). Articles 231 and 232 of that chapter recognize the dignity and value of their traditional social organization. The legal text protects and assigns to them the lands they traditionally occupied, even the soil for their physical and cultural reproduction, and recognizes them as citizens. Article 232 dismisses the prerogative of guardianship by defining how "indigenous peoples, their communities and organizations are legitimate parties to take legal action in defence of their rights and interests, with the Public Ministry intervening in all acts of the process." The overcoming of the guardianship paradigm finally marked the entry of indigenous people into the status of citizenship, even though this condition continues to be strained by the tendency to ratify a single model of citizen, or of exercising citizenship. This issue is present in most modern nations that were built on the premise of "a territory, a language, a nation," a premise that challenges their democratic plans vis-à-vis the matter of the differences and specificities of the various social components that they have historically joined together. ${ }^{2}$

\footnotetext{
${ }^{1}$ The creation of SECAD resulted from the refusal of several movements to dialogue with government agencies that were responsible for inclusion policies. It meant the reaffirmation of the diversity topic as the object of specific policies, among which were those aimed at indigenous people, quilombola people, the Romani people, and rural populations. PROLIND was accessed by means of a public call for Brazilian Public Institutions of Higher Education (IPES) to submit proposals. As of 2010, the Brazilian Ministry of Education (MEC) redefined the focus of its investment and launched the program of Continuing Education for Teachers in Indigenous School Education. This program provided for the partnership with IPES to offer refresher and specialization courses in a distance-learning format through the Open University of Brazil (UAB) and in face-to-face and blended learning formats through the National Network of Continuing Education of Teachers in Basic Education (RENAFOR). All of these policies have been heavily watered down since 2016.

2 Today, more than 305 indigenous peoples live in Brazil and speak more than 274 different languages. The indigenous population in Brazil is 896,917 people, 324,834 of whom live in cities and 572,083 in villages spread from the north to the south of the country (IBGE Census 2010). Peoples like the Kaingang (South region: states of Paraná, Santa Catarina, and Rio Grande do Sul), the Guarani (mainly in the South and Southeast regions: São Paulo, Rio de Janeiro, and Espírito Santo, and also Mato Grosso in the Central Region) and the Xakriabá (Southeast region: Minas Gerais) are among the 10 most numerous indigenous
} 


\section{The construction of proposals for specific and differentiated indigenous schooling}

The insertion of indigenous rights into the Brazilian legal apparatus obviously did not end the long path of extermination that continues in the confrontation between different logics of existence, in which, from the point of view of Western modernity, the interests of economic production prevail over the right to life of all beings. However, the inclusion of indigenous rights in the national political agenda opened up space for the official recognition of its own educational model that would ultimately trigger the formulation of specific policies for the training of indigenous teachers. ${ }^{3}$

In the Brazilian case, we can affirm that the policy of training indigenous teachers in higher education has been coordinated with the construction of indigenous school education policy. In this process, a variety of educational models emerge, depending on the ethnic, linguistic, cultural, territorial, and socioeconomic specificities of each indigenous community, including the presence or absence of educational institutions in the villages. The "specific and differentiated, intercultural, bilingual/multilingual" indigenous school education, as defined by the legal framework, would result in the strategic appropriation of a national institution. This was previously destined to dissolve the multiplicity of ethnic, linguistic, and cultural belongings, as well as the ways of organizing life in the villages, with the result that the school for indigenous peoples combined mechanisms of coercion, symbolic discreditation, and discipline. Now, in contrast to this model, as elaborated by Luciano (of the Baniwa people; 2013), the school becomes an "option to resume ethnic and community autonomy in managing the world" (Luciano 2013, p. 216).

Célia Corrêa (2018) formulates the model developed by her Xakriabá people in terms of "taming" the school:

[The idea of "taming" is] a native concept that my people use to denominate the school. Instead of using the concept of reappropriation that is widely used in anthropology, we resort to using the term taming because it is a concept developed from the struggle to tame what was wild, fearless, and therefore, attacked and violated our culture. We made this choice because the concept of reappropriation, although it may have a similar sense, does not express the impact, the violence of the arrival of schools and the purpose of implanting them in indigenous territories. (Corrêa 2018, p. 133)

According to the author, the resignification of the school based on the Xakriabá people's conception of education, as with other indigenous peoples, reverses the initial function of acculturation in order to "interact with the experiences of the community, as it was not the school that arrived first in the community, the community existed before [the] school" (Corrêa 2018, p. 133). The experiences of intercultural teacher training for indigenous people that developed within the scope of Brazilian

peoples in Brazil. Uncontacted peoples are found in some areas of the legal Amazon, for which the National Indigenous Peoples Foundation (FUNAI) reserves a specific monitoring sector.

3 For indigenous higher education, see Mato (2018). For the training of indigenous teachers, see Nascimento (2017). 
universities reveal that the proposals are organized in close association with schools in the villages and thus tend to break with the logic established in this field, where training precedes professional employment.

After almost two decades of developing intercultural degree programs, what can we extract from them in relation to teacher training? The analyses presented here are based on the practices of training indigenous teachers at the Federal UFMG since 2006, in the Intercultural Training Course for Indigenous Educators (FIEI).

In UFMG's experience, the complex negotiation that resulted in the definition of the current curricular proposal led to the prioritization of two fundamental subjects: territories and indigenous languages. With this strategic choice, the goal was to create the necessary conditions required to generate a possible space for negotiating this curricular proposal with other positions, almost entirely defined by the division of scientific knowledge categories. These categories are continuously (re)imposed either by the logic of institutional organization or by the incisive way through which scientific knowledge is placed in academic structures and activities, leaving little or no margin for expression for epistemological and ontological forms and systems that do not submit themselves to its norms.

Bringing the perspective of their territories to address aspects that we consider significant in the experiences of training indigenous teachers means going beyond the references of teacher training based on the school and assuming a relationship with indigenous peoples in a broad sense, as previously indicated. It means recognizing that this is a fundamental issue for indigenous peoples, whether it is the recognition and control of their lands or historical processes articulated with other collectives and social groups and with national society itself.

The definition of territoriality as the organization axis of the FIEI course led to the proposal of a "modular" regime in which part of the activities are carried out during intensive periods at the university, when indigenous students move from their territories to immerse themselves in the urban and academic world. In the same way, every six months the lecturers move to the villages, where they develop further academic activities while in close contact and coexistence with the local dynamics. The FIEI has been established over the years in this steady flow between the villages and the university, in incremental processes of exploration and reciprocal recognition. ${ }^{4}$

This article addresses deployments and inflections related to the fact that this centrality, which is attributed to territorial dynamics, or territoriality, has been created in different course dispositives. The experiences and analyses reported here result from the participation of the authors, who are lecturers in different areas of the course and have very different training and research backgrounds, even though they all have been FIEI coordinators at different times. We, the authors, as course

\footnotetext{
${ }^{4}$ Another decisive aspect to establishing horizontal participation of indigenous peoples in how courses were conducted was the creation of the Indigenous Consultative Council in 2010. Regarding the limits of representation and the dilemmas of indigenous recognition in the FIEI, see Gomes and Miranda (2014).
} 
lecturers, are urged to learn the logic of indigenous territories, given the multiplicity of the experiences and historical paths of the communities with whom we operate. ${ }^{5}$

It is particularly interesting to explore these diverse modes of participation by lecturers, which indicate the multiplicity of dimensions that are brought into perspective with the development of the course and show that there is no single and univocal version or vision that can be attributed to these experiences. In this light, we will discuss three of the curricular components of the course, with territoriality as the axis of approach: the teaching internship, the intermodules in a specific qualification, and the research monographs resulting from academic courses.

\section{Approaches to the notion of territory in indigenous school education}

The relationship between space and power has been a substrate for the notion of territory since it was first formulated by naturalist geographers in the nineteenth century. In that sense, which is still currently applied, the territory would designate the space for coexistence and production organized by the state. In spite of its limits, criticized and reconstituted by geography and other disciplinary fields that focused on the problematic relationship between space and power, this conception is useful, especially if combined with Foucault's assertion, according to which "territory is undoubtedly a geographical notion, but it is above all a legal-political notion: that which is controlled by a certain type of power" (Foucault 2003, p. 250). The formalization of the territory is based on political legal premises insofar as they regulate limits and, consequently, control people, things, values, and flows. To define a territory is to imprint a spatial logic; it is to regulate the use of space.

It is from this perspective that Milton Santos and colleagues (1994) reaffirmed the statement that the state defines places and territory, and these, in turn, constitute the basis, the foundation of the nation-state. Even assuming that, with globalization and the collapse of the national state, the concept of a transnational global territory came about, the same spatial logic persists, under the aegis of the power of companies and consumption strategies (see also Santos 1999). This logic crosses and recomposes territories, showing the conflict between the lived space and the global space.

It is within the scope of the used territory - that is, of territoriality as a "culturally variable construction and experience of the relationship between a specific society and its territorial base" (Gallois 2004, p. 5) - that we adjust the focus of the analysis to consider the perspective of indigenous peoples. In this sense, we are interested in the sociocultural rules that persist in the using of indigenous peoples' territories, even under the impact of colonization, which, since the beginning, imposed itself on the basis of the empty-territory metaphor to disguise a "territory full of the intentions of others" (Santos 2011). As Smith (2018) reminds us, the terra nullis doctrine was used as the basis for colonial domination, and many of the claims made

\footnotetext{
5 During this period, the following peoples participated in the course: the Xakriabá and Maxakali from Minas Gerais; the Pataxó from southern Bahia and with a presence in Minas Gerais; the Pataxó Hã-HãHãe from Bahia; the Guarani from Rio de Janeiro, Espírito Santo, and Rio Grande do Sul; the Tupinikim from Espírito Santo; and the Pankararu from Pernambuco.
} 
by indigenous peoples to the state consider "the legitimacy of them being the first peoples of that land" (Smith 2018, S. 132).

Access to land is still blocked due to a single territorial logic, that is, the appropriation of nature as a resource, which does not provide coresponsibility for places and respect for the right to life of all beings, as emphasized by Krenak (2019). Abyssal lines divide valid territories and define rules for the norms of use, of the management of the space and its resources, and of territorial organization. This logic, which establishes a fictional abstraction of unity in which humans are the measure of all things, violently contests conceptions that acknowledge "nature as a multitude of forms, including every part of ourselves, who are part of everything: 70\% water and a lot of other materials that comprise us" (Krenak 2019, p. 69).

Colonization was the process of confiscating not only occupied territory but living territory as well. Moreover, this looting took place under the aegis of extermination and with the forced displacement of indigenous peoples who survived genocide. In addition, these peoples still face invasions of their demarcated portions of land, perpetrated by murderous weapons; deforestation through arson or the devastation of tractors; spraying of pesticides on soil, animals, and people; and the establishment of large public and private enterprises in their territories. Taking all of this into account, perhaps the most appropriate thing to say is that indigenous peoples experience constant deterritorialization and reterritorialization.

In the framework of indigenous territories, while deterritorialization is the dismissal of specific logics of using a territory (among which there are discontinuity and the overlapping of functions-permanent occupations, productive activities, preservation of resources - that assume displacement), reterritorialization occurs with the symbolic reconstruction of a territory, reframing life in a space. One reads about this operation in Célia Corrêa (2018) when she refers to the Xakriabá indigenous land, whose demarcation excluded two important rivers from its limits.

The Xakriabá, who account for almost 12,000 people, have their land located in the north of Minas Gerais, in a region whose colonization process intensified in the eighteenth century in actions that led to the expulsion or extinction of the inhabitants of northern Minas Gerais. At the end of the nineteenth century, the Xakriabá had already become the only indigenous presence in the region (Santos 2013), having gone through the process of confinement in reservations and of catechesis that imposed the use of Portuguese and determined the spatial organization of the villages as well as some forms of cultivation and land use. The history of these indigenous peoples presents a rare case of existing written documentation that attests their presence on the banks of the São Francisco River in lands officially donated to them by the Portuguese crown (Santos 1997). Although they are located in a transition biome between the subtropical savanna and semi-arid regions with marked problems of drought and food production (Andrade 2019), to date the officially demarcated lands do not include the presence of any perennial watercourse.

The absence of rivers in our lands has a direct impact on our culture, territory, food and our relationship with the river. This denial of the right to access can be thought of as the violent removal of a newborn child from the family nucleus [...] This absence transforms into resistance and new forces. The last Xakriabá 
generations have also grown up feeling the identity fracture of these absences: not having gone fishing with their mother, father and grandfather; the lack of stories and knowledge that they did not hear when walking through the river; the taste of the water they did not feel; the song and strength of the charms that disappeared from there; the strangeness of the body of the foreigner who began to bathe in and later poison the river. (Corrêa, 2018, p. 26).

Thus, Célia Corrêa (2018) designates the river as the physical support of the material and symbolic losses of their territory and produces a framework that goes beyond the legally defined boundaries. By referring to the social practices of space management, reterritorialization allows us to speak about indigenous peoples' territories outside the framework of legally recognized ethnicity, of the instances of the nation-state, and of land as a possession. Reterritorialization shows how culture is intrinsically linked to territoriality. As formulated by Ratts (1999), reterritorialization refers to a field of power, is based on representations of space, and is not reduced to ownership because it concerns the appropriation of space in the sense of "a place of relationships (...) that would include a repertoire of places of affective, symbolic and political importance" (Ratts 1999, p. 6). Reterritorialization, in the experience of indigenous peoples, may involve "groups that no longer exist where their ancestors resided, portions of land lost, places to where several relatives migrated, which one wants to know" (Ratts 2004, p. 7). The living territory of the past reestablishes the boundaries for future territory by calling for life projects, including the school that starts to interact with cultural systems and territorial logics.

\section{The deterritorialization and reterritorialization of a curricular component: internship}

A territory is a space that is used and composed by the multidimensionality of what is experienced by the members of a collective. Thus, the entry of indigenous teachers in training processes conducted by higher education institutions creates a relationship with the externality of the set territorial boundaries. Indigenous students who have a degree in intercultural studies move between territories that are different in principle and then start to communicate. This is one of the meanings of interculturality: communicability between territories in their multiple dimensions. Thus, in intercultural undergraduate courses, there is great versatility in the ways of conceiving the spaces for carrying out academic activities and the way in which they can be developed.

In the field of teacher education, there is a common connection between theoretical content and educational practice developed in schools. In this case, the basic education school constitutes a place of convergence of practices, generally articulated by a curricular component, the teaching internship, a fixed point of reference for the flow between academic and school spaces.

In the FIEI, the internship program is intersected by the relationship with the indigenous communities, either within the scope of the practices and rituals in which traditional knowledge creation processes occur or in the figure of the leaders 
and "elders" who are the source for these systems of knowledge. In this process, original elements emerge because, in addition to or in the middle of the schools' teaching practice, the internship curricular component is enriched by the repertoire of places that make up the indigenous territories-history, cosmology, sociopolitical, and material organization from each people, permeated by the active participation of sages, leaders, teachers, students, and children.

The proposal of an internship for intercultural training of indigenous educators takes as a reference the fact that many students already work as teachers in their villages, or even work in other functions in these schools. Therefore, the program does not provide a process of convergence as if the school were an object external to the experience. A dialogue regarding the students' various perspectives on the school was used as a basis to improve an already territorialized rapprochement. We are interested in the description of the school apparatus from different perspectives in order to provide an overall composition that can even put into question the relations between the school and the territory. Thus, the "internship," which is a compulsory curricular component in all teacher-training courses, is displaced from its fundamental reference: the logic of training preceding teaching practice.

From this displacement comes the second reference for the development of internships: It is not about an individualized proposal, but rather a proposition articulated by a group of teachers in training from a village school. Thus, we broke with the notion of internship by school class and by academic term to organize the proposal by territory. Unlike what happens in other degrees, the school loses the reference of a fixed point when organizing the flow of the academic space-the school space. The flow of indigenous educators' intercultural training within the territories' realm is multiple, and it deterritorializes fixed points defined a priori.

A third reference: The contents of the internship are recomposed in a logic other than that of learning to teach with trained teachers. It is interesting to reflect on the dilemmas caused by the insertion of schools into indigenous peoples' territories. How can we make this institution-the school-work in favor of indigenous peoples' logic? Initially in the internship, the groups, organized by village, observe and discuss with the people who work and interact with the school and other educational forums in the village in order to territorialize the problems faced. From these questions, students identify a topic to formulate educational action projects. The construction and development of these projects goes through stages of discussion with the village leaders and schools and with other organizations in the territory that have a stake in the subject. It is through this dialogue that the proposal is solidified. Also through this dialogue, feasible conditions for educational action are created, defining the subjects involved inside and outside the school, as well as the activities and the spaces in which the educational action project will take place. The variation of topics is always dependent on territoriality. To illustrate this statement, we highlight an educational action project in a Pataxó village.

Among the Pataxó, the majority of the participants in the course were from Barra Velha, whose colloquial name, Aldeia-Mãe (Mother-Village), refers to the genocide of 1951, which caused the group to spread to other locations in Bahia and Minas Gerais. The narrative contained in Aragwaksã, the territorial management plan of the Pataxó people, gives context to what happened during the campaign of Honório 
Borges, leader of the Pataxó who sought to demarcate their lands in view of the imminent creation of the Monte Pascoal National Park, and was taken by surprise:

Two men caused an incident that triggered a violent reaction on the part of the local police in what would later be called "revolt of the Caboclos from Porto Seguro" by the press and "the 51 fire" by the Pataxó. Several indigenous people were killed by gunfire or as a result of wounds caused by the police. (Cardoso and Pinheiro 2012, p. 29)

This act led to the Barra Velha indigenous population being dispersed along the coast in the extreme south of Bahia and also to Minas Gerais, initially in the municipality of Carmésia and soon afterward in Itapecerica and Açucena. The Pataxó people identify themselves as water people, a central element of the founding myth in their cosmology. They rose from the ground when drops of rainwater fell. Water is a key life resource for inhabitants of biomes at the confluence of rivers and seas. However, the deterritorialization processes imposed limits, forcing them to settle in new territories without access to water. This is the case of the Pataxó villages in Minas Gerais, which is not a coastal state. Already removed from the sea, the Pataxó in Minas Gerais are faced with the demarcation of lands where the perennial watercourses are polluted, scarce, or unusable.

It is in this context that one of the educational action projects was established as a result of the internship at a Pataxó school in one of the villages in the municipality of Carmésia, in which the problem identified was precisely the lack of water in the school. The restricted access made it impossible to attend classes and reflected a problem that is shared by the whole village. The educational action plan was discussed with village leaders, taking into account that collection and conservation of water should be the content for educational practice at school. After diagnostic activities carried out by the students, the alternative of building a rainwater catchment box was identified in a collective effort by the village. This plan highlights the axis of a territorialized educational practice.

\section{The intermodules in the training of science teachers from an intercultural perspective}

When referring to the intercultural training of indigenous science teachers, the necessary discussion seems to go beyond how scientific and traditional knowledge intertwine and interrelate. It is also necessary to reach an understanding of how school knowledge is constituted, selected, reorganized, and restructured (Lopes 1997, p. 106) in the various schools and indigenous communities. And consequently, it is necessary to comprehend the place that scientific knowledge occupies, or can occupy, in these contexts.

In addition, we also consider it important to link the concept of intercultural education to the notion of a strategy for expanding people's capacity, in order to strengthen the agency of socially vulnerable groups and achieve a more just society (Valladares 2010, p. 41). From this perspective, the following needs are highlighted: 
1. To develop an intercultural science-education approach that promotes mutual enrichment through dialogue as a way to transform the identities and social practices of different cultural traditions through the critical use of knowledge plurality

2. To have a pluralist and sociocultural epistemological educational perspective based on the competent performance of students in the face of problematic socially relevant situations

3. To stop emphasizing universally declarative content and focus on the design of sociocultural contextualized situations to address problematic issues that are presented to students (Valladares 2010, p. 41)

At FIEI, students enroll through a specific selection process for indigenous village students, without determining ethnicity a priori. Thus, the life and natural sciences training classes are formed by students of different ethnicities. These students have ties to different territories, which involves the realization of different local practices; specific actions for the maintenance and/or recovery of biological diversity and natural resources; specific knowledge and interactions with animals, plants, springs, rivers, mangroves, and sea; memory creation about invasion processes, exploitation, and inappropriate uses of different territories; and mobilizations to solve local problems, which may be related to issues that are linked to science, such as water availability, food production, health, and waste production and disposal. Thus, the lecturers of this training course are constantly challenged to approach knowledge in a coordinated way regarding specific issues of indigenous territories, from a perspective of building a situated science. Along these lines, they seek to build a curriculum that allows dialogue with the people who are immersed in their way of life and where diversity is an academic advantage (Tavares et al. 2017, p. 169). As a recurring work strategy, activities around indigenous territories have been carried out during the intermodule periods.

Below, we present some intermodule experiences that took place in 2015 and 2016, in which a life and natural sciences class, a professor, and a graduate student from UFMG participated. These experiences demonstrate how the traffic between different territories promotes movements and displacements of conceptions about territoriality and favors an intercultural and more situated science training.

In December 2015, a life and natural sciences class participated in its first intermodule at the Barra Velha Pataxó village, located in the municipality of Porto Seguro in the southern region of the state of Bahia. In this group there were three students who lived in the village and others who came from different villages in the region. As part of the activities were carried out, there was a field trip, organized by the students, with the objective of getting to know the territory. The trip covered a walk of approximately $7 \mathrm{~km}$ along the beach.

During the walk, the group passed close to a mangrove. They also went to the home of a former student who is an indigenous teacher in the Bujigão village, which is far from the Barra Velha village and close to the tip of Corumbau, on the edge of the indigenous land. In addition, they used rafts to cross the river that separates the municipalities of Porto Seguro and Prado and visited the nonindigenous village of Corumbau. Along the way, we talked about the importance of the sea and the mangrove for the Pataxó people, both for fishing, leisure, and culture. One of the 
aspects to highlight on such a trip is to experience the unexpected as a learning opportunity. An example of such an occurrence was when an indigenous teacher invited the group to meet her students, and then they attended part of her lesson, which was in the middle of the beach, and participated in the lunch that was also held close to the beach to celebrate the end of the school year. Another important moment occurred when many students were uncomfortable about crossing the river that divides the indigenous and nonindigenous territories to visit the village of Corumbau. This discomfort was made explicit when they objected to the lecturer's idea of taking some leisure time and swimming in the sea there. Everyone said they preferred to cross the river back to the village and take the proposed swim in their territory. Thus, the visit to Corumbau was quick and silent. This scene indicates how strong the Pataxó people's relationship with their territory is, and the difficulty in reterritorializing in a markedly nonindigenous tourist location in the region. It is noteworthy that one of the challenges faced by the Pataxó people of Barra Velha, and the south of Bahia in general, is the troubled relationship with tourism. The region is an important tourist spot, with several beaches full of inns and restaurants. On the one hand, this constitutes an opportunity for the Pataxó to carry out economic activities aimed at this purpose, such as selling handicrafts and participating in cooperatives that provide sand-buggy drives to beaches and villages. On the other hand, it generates and leads to innumerable situations of prejudice and the exclusion of these indigenous people in their own territories, which are now also inhabited by businesspeople, many of whom are from other states and even countries and who invest in tourism in the region.

Another intermodule experience with field trips took place in July 2016, this time in the Xakriabá indigenous land. At that time, the group was working on the topic of water, and the lecturer asked the students to organize a field trip into the territory related to this subject. Consequently, the students proposed a route to show a "water path through Xakriabá territory." With this objective, the group used a pickup truck from the university and student motorcycles, as the itinerary included passing through three villages that were not close to each other. The itinerary was as follows: The group observed the Olho D'Água spring in the village of Barreiro Preto; they traveled to the Barra do Sumaré village to visit a small water dam and learn about an irrigation method known as "rolled water," which is used for planting beans; still in the Barra do Sumaré village, they walked to see the lapa do Roncador (snorer's cave), which is a special place for the Xakriabá people, and stopped for lunch; then they visited a large concrete dam located in the Itapicuru village. Throughout the trip, the lecturer and the graduate student were impressed by the diversity of the Xakriabá territory, which was notable in the changes in the landscape. Even during a period of drought in the region, in which much of the territory had leafless plants, brownish clay ground, and little water availability, in the places near the springs, dams, and streams of the "water circuit" the plants were green, the soil was damp, and people planted crops and vegetable gardens and used water to wash clothes, bathe, and even spend some leisure time. The point that caught both their attention the most was the Roncador, a cave with an abundant and strong waterfall, which was difficult to reach and that neither imagined existed in 
that place. In the following excerpt, the graduate student reports her experience and impressions about the Xakriabá territory:

It was then that we arrived at the most special place I came across in the Xakriabá territory, the Roncador. Inside the cave the name "snorer" seemed to make perfect sense. At the height of the drought, a powerful column of water was flowing and the noise could be felt inside one's chest. Being surprised by that hidden beauty, coming from within, reminded me of what I see in this people. A shy people, of few words, but with a very welcoming heart. It reminded me of what I am learning to see in this territory, an apparently inhospitable, dry environment, but full of hidden treasures. A land with a strong rich biodiversity in the midst of drought. (Andrade 2019, p. 87).

This field trip was also a time for students to have new experiences in the Xakriabá territory since, despite living there, due to its vast territory not everyone knew the places visited, or even when they did visit, they had few opportunities to return to them. Thus, the entire group participated in the field trip to get to know the Xakriabá territory, and, in this process, knowledge and experiences were shared, such as ways of protecting springs, planting and irrigation techniques, strategies to obtain water in places far from rivers and springs, and knowledge regarding distances and difficulties related to traveling between villages.

These examples of field trips during intermodule periods highlight how FIEI students, graduate students, and lecturers can be provided with a more specific understanding of the characteristics, practices, and problems faced in the indigenous peoples' territories that make up the territorial diversity of the course. This way of understanding, which includes the different views of the territories, is essential in enabling indigenous teachers to be trained with an intercultural scientific education in the perspective of mutual enrichment, which reinforces the agency and the critical use of knowledge plurality by indigenous peoples, as proposed by Valladares (2010). We understand that indigenous teachers must be trained for the context of life in the village collective. It is in this context that they can elect and articulate knowledge about science in order to contribute to a good life and to strengthen the autonomy of their people.

It is important to emphasize that it is also key for these teachers to make field trips to other territories, such as the urban territory of the city of Belo Horizonte and the UFMG campus, as occurs during the lesson module periods. At these times, they usually question a series of aspects that are often seen as normal by lecturers and students who live in these urban spaces, such as the excess of cars, the city noise, pollution, violence, waste of water, and the organization of housing, among others. We consider that these views, of both their own territories and of different territories, with their shared characteristics and contrasts, can constitute rich material to work with using scientific knowledge associated with other kinds of knowledge, requests, and questions produced in these spaces, both in indigenous teacher training courses and indigenous schools. 


\section{Doing research at FIEI: negotiating epistemological boundaries and defining political choices}

The final monograph is another curricular component that opens up the possibility to express the implications and relationships of different peoples with their territory. The monographs are the culmination of what is called an "academic path," that is, the combination of activities throughout the course with a research proposal that integrates the profile of indigenous teachers as researchers of their own cultures. Monographs can therefore be a way to reveal some trends through the topics and approaches that emerge in students' academic paths, as they are called at FIEI.

The process of institutionalization of the FIEI, with negotiations in the different university regulatory forums of approval, led to significant changes in some aspects of the initial proposal. Among them, it became mandatory to assume the qualifications defined by disciplinary areas of knowledge, each of which defines the annual enrolment of classes - the same configuration at that time for the training of nonindigenous teachers. ${ }^{6}$ Although the current regulations on training of indigenous teachers have allowed, since 2015, another proposal to be drawn up, this disciplinary configuration seems to be one of the pillars of deaf resistance through which are imposed the type of categorization as well as the institutional and epistemological demarcation that characterizes knowledge practices in the university. On the other hand, consensus among lecturers was established within the course that research topics could be freely selected by students, without restrictions due to disciplinary qualifications. In this way, in somehow looking for their own research agenda, what Linda Smith (2018) advocates should be the decolonization of methodologies: The definition of monograph research topics by indigenous students can be read as an expression of the interests and needs that they identify in their communities as their own research agenda, and which they reframe in terms of their possible FIEI research paths.

It is worth reaffirming here that this (im)possible dialogue between the proposals of indigenous students and the epistemological matrix that organizes knowledge at the university is gradually being constituted throughout the course. One of these convergences is proposed by a set of disciplines offered in the curriculum, which are organized in an interdisciplinary way, based on three concepts from the social and natural sciences: environment, territory, and culture. ${ }^{7}$

This proposal was built in order to challenge students from a conceptual vocabulary that mediated, over decades and through different paths, the contact and

\footnotetext{
${ }^{6}$ In a first curricular version, indigenous teachers were trained to work in three qualifications (i.e., disciplinary fields): social sciences and humanities; life and natural sciences and mathematics; and languages, arts, and literature. Subsequently, mathematics training was dissociated from life and natural sciences, remaining as the only monodisciplinary qualification.

7 In the social sciences and humanities training, the three concepts are deployed in different perspectives: indigenous societies and cultures, memory, and history. In the life and natural sSciences training, the concepts are deployed from the central themes of water and of health/quality of life. In both courses, the three concepts are addressed in terms of geopolitics and organization of the territory. There are also other curricular proposals that aim to produce/provide this mediation in relation to the different knowledge systems.
} 
the relationship of different nonindigenous agencies with indigenous communities. These are terms that many of the students already know from discussions made by the indigenous movement, and which come into play very strongly in the legal texts for guaranteeing collective rights. However, as Carneiro da Cunha (2009) verified regarding the concept of culture, it is a notion brought by science-in this case, by anthropology - which, in the specific interactions and forms within which they became part of the struggle agendas and formulations of indigenous movements, became something different and which she referred to as "culture" (that is, culture with quotes). We then have as a starting point the need to also understand this other formulation from the other concepts, which assume specific features in the research of the students of each people, based on the situations that are chosen by them as the focus of research.

Some significant cases serve to illustrate the richness presented, and the challenges faced, in producing these research paths. The research paper by Erick and Marilene Xakriabá (de Alkimim and Santos 2019) was dedicated to recovering the trajectory of partnerships and actions that gave rise to the construction of the Casa de Cultura Xakriabá (Xakriabá Culture House), which was built with traditional construction techniques and today has an agglutinating function for internal activities as well as being a meeting place for receiving external visitors. The research proposal initially seemed to be aimed at recovering the building process. This process lasted for about five years: starting from when it was proposed by some young teachers, effectively developed through partnerships with the university and foreign institutions, and finalized with the construction of the Culture House central roof. A collaborative study was carried out on the local building standards (adobe, wattle and daub, and straw), either to discuss the know-how of the techniques and their potential enhancement or to identify their weaknesses during that period, such as the scarcity of some woods that were commonly used on roofs and were no longer available for use, the poor durability of clay bricks, and the problem of the spread of Chagas disease, among others (Pinto 2009). The original aim of the research turned to the procedural and dialogical character of this project, from the initial architectural conception to research on traditional building practices and their possible resumption, some of which are no longer in use due to the massive ingress of industrialized masonry buildings into the villages, either in residences or in schools and health units. This topic brought new information to the young researchers, especially when recovering the procedural way in which the architectural plans were defined, as well as the progressive steps that led to the building standard that was actually used. In fact, the Culture House ended up being a significant building in the Sumare I village landscape and a central place for many of the Xakriabá activities. The building has become an aesthetic landmark, reaffirming what is perceived as a "traditional style house" - and in this sense it stands out clearly in relation to other buildings of the same size, all built with industrialized materials and building processes that are strange and foreign to the communities (even creating maintenance and continuity problems for these buildings). At the same time, despite the evident style that refers to local constructions, the building is original or innovative in relation to these standards, incorporating aspects that technically qualified and enhanced the construction 
standards, practices, and knowledge associated with those standards that, until then, had been subject to degradation and abandonment.

The richness of the processes associated with the building of the Culture House was one of the discoveries of the young Xakriabá researchers. However, they chose another focus toward which the conclusion, and even the practical developments of the research, were directed, and that triggered actions in the community itself. In other words, the topic was that of collectively managing such a space conceived in this way, a management that had not been defined or resolved when the building was built. This discussion was also linked to another recent and very important subject, the involvement today of different generations in decision-making and political processes, with the growing role of Xakriabá youngsters. The outcome of the research led not only to the historical record of the Culture House's building process, but to the proposition of a new shared management model, now more transparent and negotiated among the various stakeholders involved.

Another research topic that reveals this encounter between different perspectives, this time between the Pataxó from the south of Bahia, is presented to us in research that focused on the very violent historic event known as "the 51 Fire," a police attack on the village of Barra Velha (the municipality of Porto Seguro, in Bahia) which practically destroyed the entire village and caused all survivors to leave. This event dispersed the Pataxó between the states of Bahia and Minas Gerais, and some of them were never to return to that place, scarred as they were by the aggression they suffered. The topic was raised by a series of activities carried out through the course that sought to revisit history from the indigenous point of view. Different monographs were produced by students from all the peoples involved. In the case presented here (Santos 2018), the student is the daughter of one of the leaders. At the time of the police attack, her father was a three-year-old child and survived the event by being carried into the woods by his parents' relatives. Although there is written documentation about the event, it is only more recently that it has been the object of study to recover the perspective of the Pataxó themselves about this dramatic episode in their history. The Pataxó students from the course have produced a real chain of research on the subject.

The project carried out by Erilsa Pataxó attracted attention due to one aspect in particular that made it stand out from the others. In addition to proceeding with the interviews and transcriptions, as well as reading the available documents, Erilsa sought to prepare the presentation of her father's narratives so that they could be understood by her students, children between 6 and 12 years old. In the way she developed the activities related to her research, she placed herself as a bridge between the memories narrated by her father and a much younger generation-her students-whose knowledge about those facts was fragmented and varied, depending on the experiences of their own families. When presenting her research, she brought the illustrations produced by the children, which were notable for the strength of their images. Finally, she brought up the topic of traumatic memory and its difficult transmission between generations. This is a subject whose approach is complex and sensitive and that still remains unexplored for most of the violent historical events that various indigenous communities have endured. 


\section{Final remarks: challenges and learning between indigenous territories and the university}

The current context leaves on hold the analysis regarding the mechanisms by which the intercultural paradigm is established within the legal apparatus in Brazilian educational policy. Indeed, after three decades of recognition of indigenous peoples' self-determination, the discursive practices in vogue and the actions of the country's current government are, intentionally and quickly, leading to restoration of the integrationist paradigm, if not to genocide.

While we are finalizing this article, we are all-indigenous peoples and everyone else-experiencing the COVID-19 pandemic. The emergency situation that has taken place affected FIEI's activities. As with all other courses, face-to-face classes are suspended, and it is necessary to maintain contact with students by remote means. More than ever, it was clear and reaffirmed as a fundamental aspect that both the presence of indigenous people on the university campus and that of lecturers on indigenous lands had built a solid base of reciprocal trust, so that this virtual communication would work. In addition, it is possible to activate institutional collaboration devices from the course and other university forums, trying to create the best conditions with which to face the pandemic. In particular with the Xakriabá, a proposal was developed to monitor the flow of people entering and leaving the indigenous land in order to allow health services to track possible routes of contamination. ${ }^{8}$ Such an action-basically using communication strategies from social networks and mobile phones, because of difficult access to the Internet in the Xakriabá's land-can take place only due to the reciprocal knowledge that had been constituted over nearly 20 years of work and collaboration on several projects. The exposure of indigenous peoples in Brazil to the pandemic is at the highest level of vulnerability, not least due to the neglectful approach by public health policies. The strategy of strengthening community networks to prevent and monitor cases becomes almost the only possible action for coping with it.

Regarding the three curricular components presented here, we can affirm that the internship is an example of the deterritorialization of teacher education in its hegemonic conception, vis-à-vis the specific configurations assumed by indigenous schools and educational practices in different villages. The disciplines, in turn, undergo a process of reterritorialization, prompted by the intercultural logic in which they are inserted, between activities at the university and in the villages. Finally, the research developed in the academic paths can be seen here as a territorialized practice since its conception, as it allows the wide circulation of proposals and welcomes intentions and dispositions that greatly reveal the historical and cultural processes of the indigenous communities participating in the course.

Further reflection is still necessary when considering this scenario: We assume, as a starting point, the fact that we do not know everything. Moreover, we are aware that

\footnotetext{
8 The proposal was configured as an outreach activity carried out with students from the course, based on an ongoing research project on social cartography or countercartography developed in partnership between a group of researchers from UFMG (Sociology, Planning and Urbanism, Anthropology and Education, Nursing) with UFPA and Sheffield University (UK).
} 
we do not have a sufficient repertoire of knowledge and procedures—and, therefore, we are not able to count on the appropriate perspective for every situation we face. In fact, the perspectives are formed insofar as the activities are proceeding. This highlights the fact that academic paths are, in fact, colearning paths for everyone involved.

This approach, which is based on the exchange between different knowledge systems and on the interaction between people who perceive themselves as such from different perspectives, is what characterizes the version of the interculturality we try to exercise - a process that must, and needs to, be perceived as having a twoway direction, and therefore is not just a training process for indigenous students. In other words, this process should and must lead to the transformation of the whole set of relations among people, materials, and actions.

\section{References}

de Alkimim, E.C., \& Santos, M.O. (2019). Casa de Cultura Xakriabá: lugar de conhecimento, cultura, memória e história (p. 94). Belo Horizonte: Universidade Federal de Minas Gerais.

Andrade, R.C. (2019). Resistências semiáridas: sobre a produção e circulação de conhecimentos pela rede sociotécnica do milho, estiagem e os Xakriabá do norte de Minas Gerais. Belo Horizonte: Universidade Federal de Minas Gerais.

Cardoso, T. M., \& Pinheiro, M.B. (2012). Aragwaksã: Plano de Gestão Territorial do povo Pataxó de Barra Velha e Águas Belas. Brasília: Fundação Nacional do Índio.

Carneiro da Cunha, M. (2009). Cultura com aspas e outros ensaios. São Paulo: Cosac Naify.

Correa, C. N., \& Xakriabá, C. (2018). O barro, o genipapo e o giz no fazer epistemológico de autoria Xakriabá: reativação da memória por uma educação territorializada. Brasília: Universidade de Brasília.

Foucault, M. (2003). Ditos e escritos. Vol. 4. Rio de Janeiro: Forense Universitária.

Gallois, D. T. (2004). Terras ocupadas? Territórios? Territorialidades. Terras indígenas e unidades de conservação da natureza: o desafio das sobreposições (pp. 37-41). São Paulo: Instituto Socioambiental.

Gomes, A. M.R., \& Miranda, S.A. (2014). A formação de professores indígenas na UFMG e os dilemas das culturas Xakriabá e Pataxó. Políticas culturais e povos indígenas (S. 455-483). São Paulo: Cultura Acadêmica

Krenak, A. (2019). Ideias para adiar o fim do mundo. São Paulo: Editora Companhia das Letras.

Lopes, A.R.C. (1997). Conhecimento escolar: processos de seleção cultural e de mediação didática. Educação E Realidade, 22(1), 95-112.

Luciano, G. J.D. S. (2013). Educação para manejo e domesticação do mundo entre a escola ideal e a escola real: os dilemas da educação escolar indígena no Alto Rio Negro. Rio de Janeiro: Contra Capa.

Mato, D. (2018). Educação Superior e Povos Indígenas: Experiências, Estudos e Debates na América Latina e em outras Regiões do Mundo. Revista De Estudos E Pesquisas Sobre as Américas, 12(3), 29-58. https://doi.org/10.21057/repamv12n3.2018.31377.

Munduruku, D. (2012). O caráter educativo do movimento indígena brasileiro (1970-1990). São Paulo: Paulinas.

Nascimento, R. (2017). Educação Superior de Professores Indígenas no Brasil: avanços e desafios do programa de Licenciaturas Interculturais Indígenas. Educacion Superior y Sociedad, 20(20), 50-76.

Pinto, L. M. (2009). Estudo para o Plano Local de Habitação no Território Indígena Xakriabá. Projeto de Conclusão de Curso (Arquitetura e Urbanismo)_Escola de Arquitetura. Belo Horizonte: UFMG.

Ratts, A. J.P. (1999). Almofala dos Tremembé: a configuração de um território indígena. Cadernos de Campo, 8(8), 61-82.

Ratts, Alex. (2004). Traços étnicos: espacialidades e culturas negras e indígenas. Museu do Ceará, Secretaria da Cultura do Estado do Ceará.

Santos, A.F. M. (1997). Do terreno dos caboclos do Sr. São João à Terra Indígena Xakriabá: as circunstâncias da formação de um povo. Um estudo sobre a construção social de fronteiras. Dissertação de Mestrado em Antropologia. Brasília: UNB.

Santos, E. B. (2018). A história da demarcação da terra indígena Barra Velha. Belo Horizonte: Universidade Federal de Minas Gerais. 
Santos, M. (2011). Milton Santos: o espaço da cidadania e outras reflexões. São Paulo: Fundação Ulysses Guimarães.

Santos, R. M. (2013). O gê dos gerais: elementos de cartografia para a etno-história do planalto central: contribuição à antropogeografia do cerrado. Brasília: Universidade de Brasília.

Santos, M., et al. (1994). O retorno do território. Território: globalização e fragmentação (2nd edn.). São Paulo: Hucitec.

Santos, M. (1999). O território e o saber local: algumas categorias de análise. Cadernos Ippur, XIII(2), 15-25.

Silva, A.L. (2001). Uma “Antropologia da Educação” no Brasil? Reflexões a partir da escolarização indígena. Antropologia, História e Educação. A questão indígena e a escola. São Paulo: Global/MARI/FAPESP.

Smith, L. T. (2018). Descolonizando metodologias: pesquisa e povos indígenas. Curitiba: UFPR.

Tavares, M. L., Valadares, J. M., \& Junior, C. S. (2017). The science area curriculum and the construction of an intercultural pedagogy: the formation of indigenous educators at Universidade Federal de Minas Gerais (UFMG). Cadernos Cimeac. https://doi.org/10.18554/cimeac.v7i1.2172.

Valladares, L. (2010). La educación científica intercultural y el enfoque de las capacidades. Revista Iberoamericana CTS, 6(16), 39-69. 